\title{
Special Issue Editorial: Air Pollution Estimation
}

\author{
Liudmila P. Golobokova (D)
}

Limnological Institute Siberian Branch of the Russian Academy of Sciences, 664033 Irkutsk, Russia; lg@lin.irk.ru

Citation: Golobokova, L.P. Special Issue Editorial: Air Pollution

Estimation. Atmosphere 2021, 12, 655. https: / / doi.org/10.3390/ atmos12060655

Received: 14 May 2021

Accepted: 17 May 2021

Published: 21 May 2021

Publisher's Note: MDPI stays neutral with regard to jurisdictional claims in published maps and institutional affiliations.

Copyright: (C) 2021 by the author. Licensee MDPI, Basel, Switzerland. This article is an open access article distributed under the terms and conditions of the Creative Commons Attribution (CC BY) license (https:// creativecommons.org/licenses/by/ $4.0 /)$.
The key objectives at the current stage of humankind's development are the processes of atmospheric air protection. The successful issue of these tasks has a significant impact on the destiny of our whole planet, the perspectives of development of any given country, people's wellness and the quality of life. Air pollutant concentrations, which reach a critical level, are not only environmentally harmful, but negatively affect global climate change. We hope that the results of the research, submitted in this special edition, "Air Pollution Estimation", will facilitate the joint work of parties that are interested in the control of and reduction in atmospheric emissions.

Ground-level ozone $\left(\mathrm{O}_{3}\right)$, nitrogen dioxide $\left(\mathrm{NO}_{2}\right)$ and fine particles, which are known as $\mathrm{PM}_{2.5}$ (particular matters less than $2.5 \mu \mathrm{m}$ in diameter), are the major pollutants affecting human health. The relative contribution of the sources of $\mathrm{PM}_{2.5}$ and $\mathrm{PM}_{10}$ emissions to the environment in different parts of the world is thoroughly studied by Karagulian et al. [1]. However, this study does not cover every single part of the world. For example, there are no data on this basis on Russia and its neighboring countries or on some regions of South-East Asia, Central Africa and Australia. The results of the studies, contained in this special edition, will provide additional information on the environmental state of different regions. The major sources of atmospheric pollution are transport; industrial enterprises; biomass burning processes; and natural sources, including dust and sea salt. To provide a comprehensive understanding of the spatial and time-dependent inhomogeneity of the fields of atmospheric pollutant concentrations, the measurements are sometimes insufficient or mosaic. The development of methods for the reconstruction of the mean fields of atmospheric pollutant concentrations is required.

The ground-based measurements carried out in one or more sites is increasing in importance in this case. Authors Li et al. [2] successfully used the dynamically constrained interpolation methodology (DCIM) to simulate $\mathrm{PM}_{2.5}$ concentrations by utilizing groundlevel observations. They discussed the potential application of the spatial interpolation for improving $\mathrm{PM}_{2.5}$ investigations with sparse data. Eighty major cities were chosen as samples according to economic development, climate, industrial activities and topography in China. The majority of the sampled cities were scattered within the three most developed regions of China: the Beijing-Tianjin-Hebei Region, the Yangtze River Delta and the Pearl River Delta. The experimental results show that the DCIM can effectively capture variations in $\mathrm{PM}_{2.5}$ concentrations at spatiotemporal scales. However, the authors acknowledge that sparse $\mathrm{PM}_{2.5}$ measurements in a highly polluted region to some extent affect the accuracy and rationality of the interpolated distribution. The adding of the required number of observations can improve the efficiency of DCIM.

Exponential generalized autoregressive conditional heteroscedasticity (EGARCH) models are widely used in applied research. Authors Wu E.M.-Y. and Kuo S.-L. [3] proposed the particular application of this model to analyze seven air pollutants from ten air quality monitoring stations in the Kaohsiung-Pingtung Air Pollutant Control Area located in Southern Taiwan. The subject of this study was the formation mechanism of various air pollutants and the interplay among pollutants over time. In this study, the EGARCH model made it possible to track the degree of change of air pollutants in each time series in real time. 
The majority of the people in the world live in regions characterized by a high air pollution level. Air pollution is harmful for human health and people's wellness, reduces the quality of life and can negatively affect the economy. Authors Xu et al. [4] proposed a high-resolution emission inventory for one of China's new metropolitan areas using the emission factor method based on 2015 data. The estimates for sulfur dioxide $\left(\mathrm{SO}_{2}\right)$, nitrogen oxides $\left(\mathrm{NO}_{\mathrm{x}}\right)$, particulate matter $10\left(\mathrm{PM}_{10}\right)$, particulate matter $2.5\left(\mathrm{PM}_{2.5}\right)$, volatile organic compounds (VOCs) and ammonia $\left(\mathrm{NH}_{3}\right)$ emission were 132.5, 148.9, 111.6, 56.5, 119.0 and $72.0 \mathrm{kt}$, respectively. The main sources were industrial emissions, vehicle exhaust and dust. The monthly emission of the pollutants peak was in autumn and winter.

Data on emission limit values from the permitting documents of twenty-one power plants and nine metallurgical enterprises of Kazakhstan were analyzed [5], which was ranked 29th in the world's most polluted countries in 2019. Eight cities (out of fourteen) had a "high" level of atmospheric air pollution according to the Air Pollution Index in 2019. Most of the considered enterprises increased their emission limit values compared to the previous permitting period. The authors recommend updating the national air quality standards, and the definitions of air pollutants of Kazakhstan need to be based on the latest scientific knowledge.

The most distinctive feature of urban aerosol is the high concentration of organic carbon in the aerosol. While the aerosols of the background oceanic regions usually contain organic carbon within $0.1-0.8 \mu \mathrm{g} / \mathrm{m}^{3}$, that is, $5-20 \%$ of the particle mass, in the urban air, its percentage is often more than $50 \%$, and the concentrations increase up to $50-70 \mu \mathrm{g} / \mathrm{m}^{3}$ [6] and basically consist of fly ash and trace elements [7]. Coal burning is considered as a major source of organic carbon in the urban area. Trace elements, contained in coal, migrate with coal combustion products. In one study, atmospheric emissions of $\mathrm{Cr}$ from six coal-fired power plants (CFPPs), as well as the distribution of $\mathrm{Cr}$ inside these CFPPs, were measured in Guizhou Province, Southwest China [8]. The results showed that $\mathrm{Cr}$ in the feed fuel of these CFPPs ranged from 39.5 to $101.5 \mathrm{mg} \cdot \mathrm{kg}^{-1}$ (average: $68.0 \pm 24.8 \mathrm{mg} \cdot \mathrm{kg}^{-1}$ ) and was approximately four times higher than the national and global average. Due to the high $\mathrm{Cr}$ concentration in some ashes (e.g., $>500 \mathrm{mg} \cdot \mathrm{kg}^{-1}$ ) and the possible conversion of trivalent $\mathrm{Cr}$ (III) into hexavalent $\mathrm{Cr}$ (VI) during coal combustion, extreme caution should be exerted regarding the treatment of such.

One of the components of the atmosphere that negatively affects the environment, especially in megacities, is atmospheric aerosol. Air pollution is strictly connected to climate change, and many greenhouse gases and air pollutants also originate from the same sources. In this regard, the study of particles in the submicron range of sizes comes to the fore, since submicron particles mainly determine the scattering and absorption of the incoming short-wave radiation. Panchenko et al. [9] discussed the results from multiyear studies of submicron aerosol and black carbon concentrations in the troposphere of Southwestern Siberia (Russia). Over the background region of Southwestern Siberia, the annual average concentrations of submicron aerosol and black carbon were found to be maximal when the largest numbers of wildfires occurred across the entire territory of Siberia. Data of aircraft sensing in the troposphere of the background region of Southwestern Siberia (2000-2018) showed that there was an increase in black carbon concentration at all altitudes with a positive trend of $5.3 \pm 2.2 \%$ per year at an altitude of $1.5 \mathrm{~km}$. The effect of urban pollutants has been estimated. It was shown that the largest contribution of anthropogenic sources in the urban region was observed in the winter season.

There is great interest in a comprehensive study of a unique ecosystem in Lake Baikal $[10,11]$. The current law on Lake Baikal limits the activity of the permanent stationary anthropogenic sources of the aerosol in the central ecological zone, and they do not have a significant negative impact. In recent years, one of the most significant sources of atmospheric pollution in the Baikal region was the emission of smoke aerosol and trace gases from forest fires, the amount of which is increasing in the region. Despite the sporadic effects of these natural factors, they affect the pollution of various Baikal ecosystems, especially small tributaries of the lake, whose main supply is atmospheric. The concentrations 
of $\mathrm{NH}_{4}{ }^{+}, \mathrm{K}^{+}, \mathrm{NO}_{3}{ }^{-}$and $\mathrm{SO}_{4}{ }^{2-}$ which enter with submicron aerosol fraction increase in the ionic composition of the aerosol.

The Arctic has attracted increased attention in the last decade. The development of the area, the largest dynamics of climate and the vulnerability of the environment to these changes have been given priority. Special attention is devoted to studying the absorbing components of aerosol (black and brown carbon), which are formed during the combustion of different fuel and biomass types. Data accumulation during nine expeditions allowed us to carry out a statistical generalization and to obtain, for the first time, estimates of the distribution and physicochemical composition of the Arctic atmosphere in the Eurasian sector of the Arctic Ocean ( $\left.30^{\circ} \mathrm{E}-10^{\circ} \mathrm{W}\right)$ [12].

This issue examines the air condition of another unique region-Maolan National Karst Forest Park (MNKFP, SW China). One of the methods that was used for detecting air pollution was the chemical analysis of rainwater [13]. Typical ionic ratios and positive matrix factorization (PMF) model-based source apportionment suggested that anthropogenic inputs (coal combustion, industrial, traffic and agricultural emissions) contributed $51 \%$ of $\mathrm{F}^{-}, 93 \%$ of $\mathrm{NO}_{3}{ }^{-}, 62 \%$ of $\mathrm{SO}_{4}{ }^{2-}$ and $87 \%$ of $\mathrm{NH}_{4}{ }^{+}$, while the natural sources (crustal dust and sea salt) were the main sources of $\mathrm{Cl}^{-}(74 \%), \mathrm{Na}^{+}(82 \%), \mathrm{K}^{+}(79 \%), \mathrm{Mg}^{2+}(94 \%)$ and $\mathrm{Ca}^{2+}(93 \%)$.

$\mathrm{CO}_{2}$ emissions have become a key environmental contaminant that is also responsible for climate change and global warming. Two geographical groups of countries that previously belonged to the former bloc of socialist countries were used for the estimations of $\mathrm{CO}_{2}$ emission drivers [14]. The research covers Eastern European countries such as Bulgaria, Czech Republic, Hungary, Russian Federation, Poland, Romania, Slovak Republic and Ukraine, and Central Asian states such as Kazakhstan and Uzbekistan, during the period 1996-2018. The main goal of the research is to identify common drivers that determine carbon dioxide emissions in selected states.

Although the factors of the impact on human health are of major concern, air pollution also has a significant impact on the destruction of buildings, monuments and cultural heritage sites. Chiantore O. and Poli T. [15] discussed the nature and quality of volatile compounds emitted from materials used in the manufacturing and finishing of museum display cases and the harm that can be caused to the heritage objects.

Air pollution is caused by air pollutant emissions to the atmosphere from a variety of sources, both of human and natural origin. The granulometric distribution of dusty events that has occurred over the last 20 years in the Caribbean islands of Puerto Rico (PR), Guadeloupe (GPE) and Barbados (BAR) was studied and compared to the extreme event of June 2020. To carry out this study, different types of data (ground-based, satellites, model and soundings) on several sites were used in order to describe the dust events in terms of seasonality, intensity, frequency and particle size behavior [16].

The data collected indicate that the actual level of atmospheric air pollution in different regions of the world is one of the main problems contributing to the sanitary state of the environment, which relates to everyone, regardless of whether one lives in a low-, middleor high-income country.

Funding: This research received no external funding.

Acknowledgments: The editors would like to thank the author for their contributions, the reviewers for their comments and the editorial office for the support in publishing this issue.

Conflicts of Interest: The authors declare no conflict of interest.

\section{References}

1. Karagulian, F.; Belis, C.A.; Dora, C.F.C.; Prüss-Ustün, A.M.; Bonjour, S.; Adair-Rohani, H.; Amann, M. Contributions to cities' ambient particulate matter (PM): A systematic review of local source contributions at global level. Atmos. Environ. 2015, 120, 475-483. [CrossRef]

2. Li, N.; Xu, J.; Lv, X. Application of Dynamically Constrained Interpolation Methodology in Simulating National-Scale Spatial Distribution of PM2.5 Concentrations in China. Atmosphere 2021, 12, 272. [CrossRef] 
3. Wu, E.M.-Y.; Kuo, S.-L. VARMA-EGARCH Model for Air-Quality Analyses and Application in Southern Taiwan. Atmosphere 2020, 11, 1096. [CrossRef]

4. Xu, B.; You, X.; Zhou, Y.; Dai, C.; Liu, Z.; Luo, D.; Peng, H. The Study of Emission Inventory on Anthropogenic Air Pollutants and Source Apportionment of PM2.5 in the Changzhutan Urban Agglomeration, China. Atmosphere 2020, 11, 739. [CrossRef]

5. Assanov, D.; Zapasnyi, V.; Kerimray, A. Air Quality and Industrial Emissions in the Cities of Kazakhstan. Atmosphere 2021, 12, 314 [CrossRef]

6. Zhang, Q.; Jimenez, J.L.; Canagaratna, M.R.; Allan, J.D.; Coe, H.; Ulbrich, I.; Alfarra, M.R.; Takami, A.; Middlebrook, A.M.; Sun, Y.L.; et al. Ubiquity and dominance of oxygenated species in organic aerosols in anthropogenically-influenced Northern Hemisphere midlatitudes. Geophys. Res. Lett. 2007, 34. [CrossRef]

7. Vu, T.V.; Delgado-Saborit, J.M.; Harrison, R.M. Review: Particle number size distributions from seven major sources and implications for source apportionment studies. Atmos. Environ. 2015, 122, 114-132. [CrossRef]

8. Li, Z.; Wang, Q.; Xiao, Z.; Fan, L.; Wang, D.; Li, X.; Du, J.; Cheng, J. Behaviors of Chromium in Coal-Fired Power Plants and Associated Atmospheric Emissions in Guizhou, Southwest China. Atmosphere 2020, 11, 951. [CrossRef]

9. Panchenko, M.; Yausheva, E.; Chernov, D.; Kozlov, V.; Makarov, V.; Popova, S.; Shmargunov, V. Submicron Aerosol and Black Carbon in the Troposphere of Southwestern Siberia (1997-2018). Atmosphere 2021, 12, 351. [CrossRef]

10. Zhamsueva, G.; Zayakhanov, A.; Tcydypov, V.; Dementeva, A.; Balzhanov, T. Spatial-Temporal Variability of Small Gas Impurities over Lake Baikal during the Forest Fires in the Summer of 2019. Atmosphere 2021, 12, 20. [CrossRef]

11. Golobokova, L.; Khodzher, T.; Khuriganova, O.; Marinayte, I.; Onishchuk, N.; Rusanova, P.; Potemkin, V. Variability of Chemical Properties of the Atmospheric Aerosol above Lake Baikal during Large Wildfires in Siberia. Atmosphere 2020, 11, 1230. [CrossRef]

12. Sakerin, S.M.; Kabanov, D.M.; Makarov, V.I.; Pol'kin, V.V.; Popova, S.A.; Chankina, O.V.; Pochufarov, A.O.; Radionov, V.F.; Rize, D.D. Spatial Distribution of Atmospheric Aerosol Physicochemical Characteristics in the Russian Sector of the Arctic Ocean. Atmosphere 2020, 11, 1170. [CrossRef]

13. Zeng, J.; Han, G. Rainwater Chemistry Reveals Air Pollution in a Karst Forest: Temporal Variations, Source Apportionment, and Implications for the Forest. Atmosphere 2020, 11, 1315. [CrossRef]

14. Li, R.; Jiang, H.; Sotnyk, I.; Kubatko, O.; Almashaqbeh, Y.A.I. The $\mathrm{CO}_{2}$ Emissions Drivers of Post-Communist Economies in Eastern Europe and Central Asia. Atmosphere 2020, 11, 1019. [CrossRef]

15. Chiantore, O.; Poli, T. Indoor Air Quality in Museum Display Cases: Volatile Emissions, Materials Contributions, Impacts. Atmosphere 2021, 12, 364. [CrossRef]

16. Euphrasie-Clotilde, L.; Plocoste, T.; Brute, F.-N. Particle Size Analysis of African Dust Haze over the Last 20 Years: A Focus on the Extreme Event of June 2020. Atmosphere 2021, 12, 502. [CrossRef] 